\title{
Some important aspects in Moringa oleifera Lam. micropropagation
}

\author{
Ahmed HASSANEIN ${ }^{1}$, Jehan SALEM ${ }^{1}$, Fayza FAHEED ${ }^{1}$ and Abdullah EL-NAGISH ${ }^{1} *$
}

Received November 24, 2018; accepted January 28, 2019.

Delo je prispelo 24. novembra 2018, sprejeto 28. januarja 2019.

\begin{abstract}
Type and source of explant as well as the type of cytokinin were important factors for successful moringa micropropagation. Explants obtained from in vitro grown plant materials were better than others obtained from soil growing seedlings. In addition, nodal segments were better than shoot cuttings in terms of number of shoots/ explants, frequency of shoot formation and number of nodes/shoot. While callus formation on the base of nodal segment on BAP containing media were higher than those of KIN, especially under the influence of high concentration as an aspect of vitrification, BAP was better than KIN in moringa multiplication. Low nutrient medium (half strength MS) supplemented with $0.5 \mathrm{mg} \mathrm{l}^{-1}$ IAA was essential for successful root formation. The suitable conditions for moringa micropropagation on full strength MS or SH may exert low stress and low need to raise the expression of SOD and POX. On the other side, stress due to over increase of chemical components of double MS medium or low nutrient content of half strength MS, B5 or WPM expressed the highest number and staining intensity of SOD and POX bands, vice versa was detected in case of CAT.
\end{abstract}

Key words: medium type; shoot multiplication; cytokinins; gene expression; isoenzymes; micropropagation; antioxidant enzymes; type of explant

Abbreviations: benzyl amino purine (BAP), kinetin (KIN), esterases (ESTs), glutamate oxaloacetate transaminases (GOTs), superoxide dismutases (SODs), peroxidases (POXs)

\section{IZVLEČEK}

\section{NEKATERI POMEMBNI VIDIKI V MIKROPROPAGACIJI MORINGE (Moringa oleifera Lam.)}

Vir in vrsta izsečkov kot tudi vrsta citokininov sta pomembna dejavnika za uspešno mikropropagacijo moringe. Izsečki, pridobljeni iz in vitro vzgojenih rastlin so bili boljši kot tisti pridobljeni iz sejank vzgojenih v tleh. Dodatno so bili izsečki nodijev boljši kot iz ostalih delov poganjka glede na število nastalih poganjkov na izseček, pogostost tvorbe poganjkov in število nodijev na poganjek. Tvorba kalusa na bazi nodialnega segmenta je bila boljša $v$ gojišču z BAP kot v gojišču s KIN, še posebej zaradi vpliva večjih koncentracij je bil pri mikropropagaciji moringe $\mathrm{z}$ vidika vitrifikacije BAP boljši kot KIN. Gojišče z majhno vsebnostjo hranil (polovični MS) z dodatkom $0,5 \mathrm{mg} \mathrm{l}^{-1}$ IAA je bilo odločilno za tvorbo korenin. Primerne razmere za mikropropagacijo moringe na polnomočnih gojiščih MS ali SH so manj stresne in ne vzpodbudijo tvorbo SOD in POX. Po drugi strani je stres zaradi povečanja spojin $\mathrm{v}$ dvojnem gojišču MS ali $\mathrm{v}$ polovičnih gojiščih MS, B5 ali WPM z majhno količino hranil vzpodbudil največjo ekspresijo SOD in POX, kar se je pokazalo $\mathrm{z}$ največjim številom in močnejšo obarvanostjo eletroforeznih trakov, obratno je bilo ugotovljeno v primeru CAT.

Ključne besede: tip gojišča; razmnoževanje poganjkov; citokinini; izražanje genov; izoencimi; mikropropagacija; antioksidacijski encimi; vrsta izsečkov

Okrajšave: benzil amino purin (BAP), kinetin (KIN), esteraze (ESTs), glutamat oksaloacetat transaminaze (GOTs); superoksid dizmutaze (SODs); peroksidaze (POXs)

\section{INTRODUCTION}

Moringa oleifera Lam., commonly known as moringa, is a distinguished member of the monogeneric family Moringaceae. Moringa is a perennial soft wood tree, native to the western and sub-Himalayan tracts including India, Pakistan, Asia Minor, Africa and Arabia. Moringa is now being cultivated in many other

1 Botany and Microbiology Department, Faculty of Science, Sohag University, 82524 Sohag, Egypt; *corresponding author: ael.nagish@yahoo.com 
places like the Caribbean Islands, Central America, North and South America, Cambodia, the Philippines and Egypt (Morton, 1991; Fahey, 2005). Moringa is considered the most nutrient-dense plant yet discovered where fruits, leaves, flowers and immature capsules of this tree are highly nutritious and used in many countries all over the world (Anwar and Bhanger, 2003). Various types of antioxidants such as ascorbic acid, flavonoids, phenolics and carotenoids present in moringa leaves (Dillard et al., 2000; Siddhuraju et al., 2003). Besides its food uses, moringa is used as animal feed (Sanchez et al., 2006). Seeds powder can be used for water purification due to its antimicrobial and coagulant properties (Ndabigengesere and Narasiah, 1998; Suarez et al., 2003; Bhatia et al., 2007). Moringa is also reported to possess anti-inflammatory, antimicrobial, antioxidant, anticancer, cardiovascular, hepatoprotective, anti-ulcer, diuretic and anticholestrolmic properties. (Cáceres et al., 1992; Murakami et al., 1998; Guevara et al., 1999; Siddhuraju et al., 2003; Stephenson and Fahy, 2004).

A large scale production of moringa is needed because of its nutritional and medicinal importance. Germination of moringa seeds decreased with the increase in time between harvesting and sowing where it reaches $7.5 \%$ in three months (Sharma et al., 1982). This hinders the use of seeds for moringa cultivation. Also, trees propagated from seeds showed genotypic and phenotypic variations that resulted in variation in production and nutritional values (Riyathong et al., 2010; Salem 2016). Propagation through stem cuttings results in trees with inferior fruits and shallow root system making them more drought-susceptible (Church World Service, 2000). This method of propagation reduces the yield and life of mother plant (Islam et al., 2005). Consequently, micropropagation was essential prerequisite of propagation of elite tree. Moringa micropropagation was accomplished using tissues obtained from seedling or mature trees (Islam et al., 2005; Riyathong et al., 2010; Förster et al., 2013; Salem, 2016; Zhang et al., 2017). Vitrification and the associated somaclonal variation are two aspects retarding the application of in vitro techniques as effective vegetative micropropagation tools in moringa (Hassanein et al., 2008; Mirzai et al., 2015; Salem, 2016; Hassanein et al., 2018).

In vitro culture conditions exert stress which need (Chen and Ziv, 2001; Rojas-Martínez et al., 2010) induction of some antioxidant enzymes such as superoxide dismutase (SOD), catalase (CAT) and peroxidase (POX) to help the cultured tissues to avoid the exerted stress (Pawar and Panneerselvam, 2012; Devi et al., 2013). Under stress conditions, SOD plays its role by catalyzing the dismutation of excess $\mathrm{O}_{2}^{-}$into $\mathrm{O}_{2}$ and $\mathrm{H}_{2} \mathrm{O}_{2}$. Toxic $\mathrm{H}_{2} \mathrm{O}_{2}$ is further catalyzed by CAT, POX and other enzymes to form $\mathrm{H}_{2} \mathrm{O}$ and $\mathrm{O}_{2}$ (Ueda et al., 2013; Rout et al., 2013; Zhang et al., 2017).

The response of different types of explant to the same culture condition is varied due to the difference in endogenous plant hormones they have (Kumar and Reddy, 2011). Explants derived from in vitro grown plant materials are recommended for micropropagation, where they have better potential to organogenesis as compared to explants obtained from in vivo grown plants (Kumar and Reddy, 2011). While different types of plant media such as B5 (Gamborg et al., 1968), SH (Schenk and Hildebrandt, 1972), WPM (Lloyd and McCown, 1980) and MS (Murashige and Skoog, 1962) have been used for regeneration of different plant species. MS was used to induce regeneration on different types of explants belongs to different plant species (Hassanein et al., 2008; 2015; Kumar and Reddy, 2011). While some plant species response similarly to several media, generally plant species express preference response for a specific medium when certain explant is used (McCown and Sellmer, 1987). For example, weaker salt medium such as WPM promoted the formation of axillary bud development in forest plant species (McCown and Sellmer, 1987) and it was probably due to lower concentration of salts and sucrose than those of B5 and MS (Bhatt and Dhar, 2004). In the other side, application of double strength MS medium resulted in increase the number of formed shoots compared to full strength MS (Gnamien et al., 2013).

The best concentration and type of growth regulators which are necessary to stimulate organogenesis on in vitro cultured explant should be determined for establishment of tissue culture protocol (Parzymies and Dąbsk, 2012). In addition, determination of optimal media type, and type and source of explants are important factors for successful micropropagation. The best condition for moringa micropropagation is not correctly determined and still needs several studies. Consequently, the aim of the present work was to determine the best type of media, cytokinin and explant to establish successful in vitro propagation protocol in moringa. In addition, the effect of nutrient strength of the cultured media on isoenzyme patterns of the cultured explant during shoot multiplication was the second aim of this work. 


\section{MATERIALS AND METHODS}

\subsection{Shoot multiplication using soil-obtained explants under the influence of different concentrations of BAP or KIN}

To establish shoot culture of moringa plant, seeds were germinated in plastic pots filled with clay soil in Central Laboratory of Genetic Engineering, Sohag University for six days. Nodal segments and shoot cuttings (upper part of shoots including shoot tip) obtained from these soil growing seedlings were subjected for sterilization using $70 \%$ ethyl alcohol for three $\min$ and $0.1 \% \mathrm{HgCl}_{2}$ for further three min with continuous shaking. Plant materials were rinsed 3 times in sterilized deionized water, three minutes each. After sterilization, the ends of each explant were discarded. Segments in length of $1.0-1.5 \mathrm{~cm}$ long were transferred to MS medium (Murashige and Skoog, 1962) supplemented with different concentrations of BAP or KIN $(0.28,0.56$, 1.12 and $2.24 \mathrm{mg} \mathrm{l}^{-1}$ ).

\subsection{Shoot multiplication using in vitro obtained nodal segments under the influence of different concentrations of BAP or KIN}

Sterilized moringa seeds were aseptically placed in 250 $\mathrm{ml}$ glass jars contained sterilized cotton pieces wetted with deionized water. Cultures were incubated for 4 days at $28 \pm 2{ }^{\circ} \mathrm{C}$ under dark conditions, then they were transferred to 16 -h photoperiod at the same temperature for further 2 days. After six days, seedlings were used to establish shoot culture.

Nodal segments obtained from in vitro grown seedlings were cultured on MS medium supplemented with 0.56 $\mathrm{mg}^{-1} \mathrm{BAP}$ for 2 weeks then nodal segments were used as plant materials. They were subcultured on MS medium supplemented with different concentration of BAP or KIN $\left(0.28,0.56,1.12\right.$ and $\left.2.24 \mathrm{mg}^{-1}\right)$. MS basal medium was used as a control.

\subsection{Effect of media type and strength on shoot multiplication}

Nodes of about 1.0-1.5 cm were excised from aseptically grown seedlings and cultured on half, double, full MS (Murashige and Skoog, 1962), SH (Schenk and Hildebrandt, 1972) and B5 (Gamborg et al., 1968) media and Woody Plant Medium (Lloyd and McCown, 1980). Each medium was supplemented with $0.56 \mathrm{mg} / 1 \mathrm{BAP}$.

\subsection{Incubation conditions}

All cultures were incubated at $28 \pm 2{ }^{\circ} \mathrm{C}$ under 16 -h daily light at $100 \mu \mathrm{mol} \mathrm{m}-2 \mathrm{~s}-1$ for 3 weeks. Number of shoots per explants, length of shoots $(\mathrm{cm})$ and number of nodes per shoots were determined.

\subsection{Protein extraction and isoenzyme}

Shoots grown for 21 days under the influence of the different media were collected and subjected for gene expression analysis. One gram of fresh plant materials was ground in $1 \mathrm{ml}$ extraction buffer in a mortar at $4{ }^{\circ} \mathrm{C}$. Extraction buffer consisted of $0.1 \mu \mathrm{M}$ Tris-HCl, $\mathrm{pH} 7.0$ and $0.002 \mathrm{M}$ cysteine. The homogenate was centrifuged at $13500 \mathrm{rpm}$ at $4{ }^{\circ} \mathrm{C}$ for $15 \mathrm{~min}$. Supernatants were collected for immediate electrophoresis in $7.5 \%$ polyacrylamide slab gels. Gels were run at $24 \mathrm{~mA}$ for 6$\mathrm{h}$ at $10^{\circ} \mathrm{C}$ in $0.025 \mathrm{M}$ Tris $+0.129 \mathrm{M}$ glycine buffer $\mathrm{pH}$ 8.9. Peroxidase (POX) was stained according to the method of Siegel and Galston, 1967, superoxide dismutase (SOD) according to Beauchamp and Fridovich, 1971, glutamate oxaloacetic transaminase (GOT) and esterase (EST) according to the method of Brewer, 1970.

\subsection{Statistical analysis}

Three replicates with thirty explants for each treatment were used in all experiments. Data were statistically analyzed by ANOVA and compared using the least significant difference (LSD) test at $5 \%(*)$ and $1 \%(* *)$ levels as described by Snedecor and Cochran, (1980).

\section{RESULTS}

Two types of explants obtained from soil growing seedling were used to establish protocol for moringa micropropagation. When shoot cuttings were used as an explant and cultured on MS medium supplemented with different concentrations of BAP (Table 1) for three weeks, $0.56 \mathrm{mg} \mathrm{l}^{-1}$ was the best, where the highest regeneration frequency, number of shoots/explant and growth parameters were obtained. The lowest response was detected when shoot segments were cultured on growth regulators free medium but they showed the highest number of nodes/shoot and the formation of adventitious roots (Fig. 1). Increasing BAP concentration more than 0.5 resulted in decrease in number of shoots/explant especially when $2.24 \mathrm{mg} \mathrm{l}^{-1}$ 
BAP was used). Fresh mass/cluster increased significantly in shoot cuttings cultured on MS medium supplemented with different concentrations of BAP up to $1.12 \mathrm{mg} \mathrm{l}^{-1}$. Shoot cuttings cultured on MS medium supplemented with different concentrations of BAP showed significant increase in shoot length, fresh mass/shoot and number of nodes/explant compared to control.

Table 1: Shoot segments from six-day old soil growing seedling cultured for three weeks on MS medium supplemented with different concentrations of BAP or Kin.

\begin{tabular}{cccccccc}
\hline$\left(\mathrm{mg} \mathrm{l}^{-1}\right)$ & PGR & $\begin{array}{c}\text { Freq. of } \\
\text { shoot } \\
\text { formation } \\
\%\end{array}$ & $\begin{array}{c}\text { Number of } \\
\text { shoots/ } \\
\text { explants }\end{array}$ & $\begin{array}{c}\text { Fresh mass/ } \\
\text { Cluster }(\mathrm{g})\end{array}$ & $\begin{array}{c}\text { Length of } \\
\text { shoot }(\mathrm{cm} .)\end{array}$ & $\begin{array}{c}\text { Fresh mass/ } \\
\text { Shoot }(\mathrm{g})\end{array}$ & $\begin{array}{c}\text { No } \\
\text { nodes/shoot }\end{array}$ \\
\hline 0 & control & 40.0 & $1.67 \pm 0.57$ & $0.27 \pm 0.06$ & $2.77 \pm 0.71$ & $0.02 \pm 0.00$ & $2.33 \pm 0.57$ \\
0.28 & BAP & 70.0 & $1.67 \pm 0.58^{\mathrm{a}}$ & $0.57 \pm 0.06^{\mathrm{b}}$ & $2.73 \pm 0.25^{\mathrm{a}}$ & $0.09 \pm 0.01^{\mathrm{c}}$ & $1.33 \pm 0.58^{\mathrm{c}}$ \\
& Kin & 63.3 & $1.33 \pm 0.57^{\mathrm{a}}$ & $0.09 \pm 0.01^{\mathrm{b}}$ & $2.80 \pm 0.68^{\mathrm{a}}$ & $0.03 \pm 0.01^{\mathrm{a}}$ & $1.80 \pm 0.25^{\mathrm{a}}$ \\
0.56 & BAP & 86.7 & $2.00 \pm 0.00^{\mathrm{a}}$ & $0.57 \pm 0.09^{\mathrm{b}}$ & $2.87 \pm 0.23^{\mathrm{a}}$ & $0.05 \pm 0.01^{\mathrm{c}}$ & $1.66 \pm 0.58^{\mathrm{c}}$ \\
& Kin & 83.3 & $2.67 \pm 0.57^{\mathrm{c}}$ & $0.52 \pm 0.08^{\mathrm{b}}$ & $4.80 \pm 0.75^{\mathrm{c}}$ & $0.07 \pm 0.02^{\mathrm{c}}$ & $4.30 \pm 0.86^{\mathrm{c}}$ \\
& BAP & 76.7 & $1.67 \pm 0.56^{\mathrm{a}}$ & $0.26 \pm 0.06^{\mathrm{a}}$ & $2.83 \pm 0.47^{\mathrm{a}}$ & $0.05 \pm 0.01^{\mathrm{c}}$ & $1.00 \pm 0.00^{\mathrm{c}}$ \\
2.12 & Kin & 70.0 & $2.67 \pm 0.57^{\mathrm{c}}$ & $0.83 \pm 0.10^{\mathrm{c}}$ & $5.30 \pm 0.72^{\mathrm{c}}$ & $0.08 \pm 0.03^{\mathrm{c}}$ & $2.67 \pm 0.67^{\mathrm{a}}$ \\
& BAP & 63.3 & $1.00 \pm 0.00^{\mathrm{c}}$ & $0.21 \pm 0.05^{\mathrm{a}}$ & $2.40 \pm 0.44^{\mathrm{a}}$ & $0.10 \pm 0.01^{\mathrm{c}}$ & $1.33 \pm 0.58^{\mathrm{c}}$ \\
& Kin & 76.7 & $3.33 \pm 0.57^{\mathrm{c}}$ & $0.36 \pm 0.08^{\mathrm{a}}$ & $2.93 \pm 0.20^{\mathrm{a}}$ & $0.05 \pm 0.01^{\mathrm{c}}$ & $4.67 \pm 0.57^{\mathrm{c}}$ \\
& LSD at $5 \%$ & & 0.40 & 0.17 & 3.33 & 0.03 & 0.54 \\
\hline
\end{tabular}

Values are means of three replicates \pm standard deviation (SD). Different letters indicate statistically significant differences between groups (mean $\pm \mathrm{SD}$, a not significant, b significant at $p<0.05$, c highly significant at $p<0.01$ ).

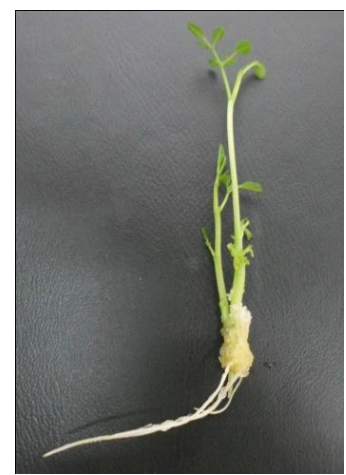

Figure 1: Photograph shows in vitro shoot regeneration on shoot segments under the influence MS free of hormones

When nodal segments were used (Table 2) as explants, the frequency of shoot formation, number of shoots/explant, fresh mass/cluster and number of nodes/explant were higher than those of shoot cuttings
(Table 1). The increase of fresh mass/cluster was associated with decrease in shoot length and appearance of callus on the base of nodal segment where its size increased with increase of BAP (Fig. 2). 
Table 2: Nodal segments excised from six-day old soil growing seedling cultured for three weeks on MS medium supplemented with different concentrations of BAP or Kin.

\begin{tabular}{|c|c|c|c|c|c|c|c|}
\hline$\left(\mathrm{mg} \mathrm{l}^{-1}\right)$ & PGR & $\begin{array}{c}\text { Freq. of } \\
\text { shoot } \\
\text { formation } \\
\%\end{array}$ & $\begin{array}{l}\text { Number of } \\
\text { shoots/ } \\
\text { explants }\end{array}$ & $\begin{array}{l}\text { Fresh mass/ } \\
\text { Cluster }(\mathrm{g})\end{array}$ & $\begin{array}{l}\text { Length of } \\
\text { shoot }(\mathrm{cm} .)\end{array}$ & $\begin{array}{c}\text { Fresh mass/ } \\
\text { Shoot }(\mathrm{g})\end{array}$ & $\begin{array}{c}\text { No } \\
\text { nodes/shoot }\end{array}$ \\
\hline 0 & control & 53.3 & $2.00 \pm 0.00$ & $0.51 \pm 0.03$ & $2.83 \pm 0.57$ & $0.06 \pm 0.01$ & $2.33 \pm 0.57$ \\
\hline \multirow{2}{*}{0.28} & BAP & 76.7 & $2.33 \pm 0.58^{\mathrm{a}}$ & $0.45 \pm 0.09^{\mathrm{a}}$ & $3.00 \pm 0.20^{\mathrm{a}}$ & $0.05 \pm 0.01^{\mathrm{a}}$ & $2.00 \pm 0.00^{\mathrm{a}}$ \\
\hline & Kin & 76.7 & $1.67 \pm 0.57^{\mathrm{a}}$ & $0.16 \pm 0.05^{\mathrm{c}}$ & $2.50 \pm 0.54^{\mathrm{a}}$ & $0.02 \pm 0.00^{\mathrm{c}}$ & $1.30 \pm 0.30^{c}$ \\
\hline \multirow{2}{*}{0.56} & BAP & 100.0 & $5.75 \pm 0.50^{\mathrm{c}}$ & $0.88 \pm 0.14^{c}$ & $2.73 \pm 0.25^{\mathrm{a}}$ & $0.06 \pm 0.01^{\mathrm{a}}$ & $2.33 \pm 0.58^{\mathrm{a}}$ \\
\hline & Kin & 100.0 & $3.75 \pm 0.50^{c}$ & $0.66 \pm 0.07^{\mathrm{c}}$ & $6.53 \pm 0.45^{c}$ & $0.09 \pm 0.04^{\mathrm{c}}$ & $4.67 \pm 0.57^{c}$ \\
\hline \multirow{2}{*}{1.12} & BAP & 86.7 & $4.00 \pm 1.00^{c}$ & $0.84 \pm 0.12^{c}$ & $1.77 \pm 0.21^{\mathrm{c}}$ & $0.05 \pm 0.02^{\mathrm{a}}$ & $1.66 \pm 0.58^{c}$ \\
\hline & Kin & 86.7 & $2.00 \pm 0.00^{\mathrm{a}}$ & $0.23 \pm 0.06^{\mathrm{c}}$ & $2.50 \pm 0.52^{\mathrm{a}}$ & $0.03 \pm 0.01^{\mathrm{c}}$ & $2.33 \pm 0.57^{\mathrm{a}}$ \\
\hline \multirow{4}{*}{2.24} & BAP & 90.0 & $2.67 \pm 0.58^{\mathrm{a}}$ & $0.99 \pm 0.24^{\mathrm{c}}$ & $1.23 \pm 0.25^{\mathrm{c}}$ & $0.04 \pm 0.01^{b}$ & $1.66 \pm 0.58^{c}$ \\
\hline & Kin & 93.3 & $3.67 \pm 0.57^{\mathrm{c}}$ & $0.56 \pm 0.05^{\mathrm{a}}$ & $3.67 \pm 0.58^{c}$ & $0.06 \pm 0.01^{\mathrm{a}}$ & $3.33 \pm 0.57^{c}$ \\
\hline & LSD at $5 \%$ & & 0.80 & 0.11 & 0.40 & 0.01 & 0.50 \\
\hline & LSD at $1 \%$ & & 1.56 & 0.26 & 1.33 & 0.02 & 0.98 \\
\hline
\end{tabular}

Values are means of three replicates \pm standard deviation (SD). Different letters indicate statistically significant differences between groups (mean $\pm \mathrm{SD}$, a not significant, $\mathrm{b}$ significant at $p<0.05$, $\mathrm{c}$ highly significant at $p<0.01$ ).
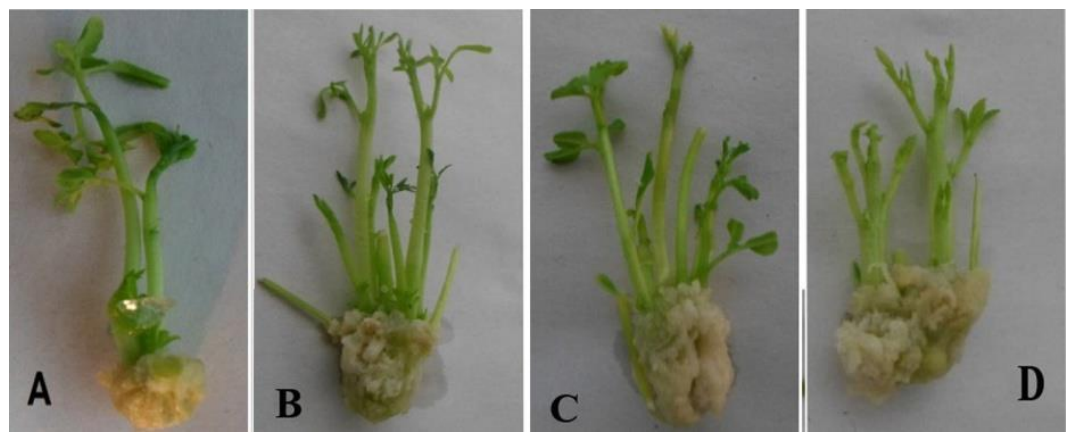

Figure 2: Photographs show in vitro shoot regeneration from nodal cuttings under the influence of different concentrations of BAP for three weeks; 0.28 (A), 0.56 (B), 1.12 (C) and $2.24 \mathrm{mg} .1^{-1}$ (D)

When shoot segments of soil grown seedlings were used as explants and cultured on MS medium containing different concentration of KIN, they expressed higher values of the all measured parameters (Table 1), especially under relatively high concentrations (1.12 and $2.24 \mathrm{mg} \mathrm{l}^{-1}$ ), than those of BAP. Nodal segments expressed higher values of shoot number/explant than shoot cutting irrespective the concentration of KIN (Table 2). Irrespective the type of explant, shoot length and number of nodes/shoot on MS medium supplemented with KIN was higher than those of BAP. On the other side, when the best concentration of both cytokinins $\left(0.56 \mathrm{mg} \mathrm{l}^{-1}\right)$ was used, the number of shoots on MS with BAP was higher that of KIN (Table 2). Callus at the base of nodal segments on KIN containing medium (Fig. 3) was lower than that of BAP, and it was not strongly influenced by the concentration of KIN. 


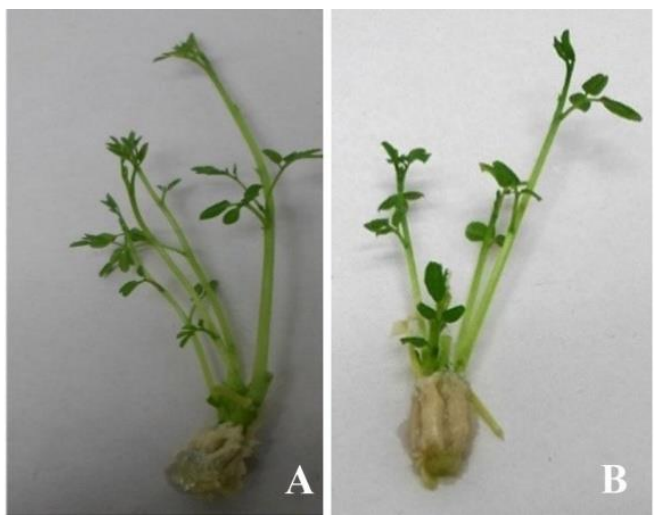

Figure 3: Photograph shows in vitro shoot regeneration under the influence of different concentrations of Kin: (A) nodal segment were cultured for three weeks on 0.56 (A) or $2.24 \mathrm{mg} . \mathrm{l}^{-1} \mathrm{Kin}(\mathrm{B})$

For moringa multiplication, the best source of explants were in vitro grown shoots where plant materials were established as shoot culture on MS medium supplemented with different concentrations of BAP or KIN (Tables 3 and 4). Number of shoots obtained from in vitro grown plant materials (Tables 3 and 4 ) was higher than that obtained from soil grown plant materials (Tables 1 and 2). The best cytokinin concentration was $0.56 \mathrm{mg} \mathrm{l}^{-1}$ of BAP or KIN, where it expressed the highest number of shoots/explant. Shoot multiplication using $0.56 \mathrm{mg} \mathrm{l}^{-1} \mathrm{BAP}$ was better than that of KIN. On the other side, explants subcultured on media containing the highest concentration of BAP or KIN (2.24 $\left.\mathrm{mg}^{-1}\right)$ expressed high values of fresh mass/cluster but low values of shoot length as an aspect of vitrification.

Table 3: Nodal segments explants obtained from in vitro grown shoots were cultured for three weeks on MS medium supplemented with different concentrations of BAP

\begin{tabular}{ccccccc}
\hline$\left(\mathrm{mg} \mathrm{l}^{-1}\right)$ & PGR & $\begin{array}{c}\text { Number of } \\
\text { shoots/ explants }\end{array}$ & $\begin{array}{c}\text { Fresh mass/ } \\
\text { Cluster } \\
(\mathrm{g})\end{array}$ & $\begin{array}{c}\text { Length of shoot } \\
(\mathrm{cm} .)\end{array}$ & $\begin{array}{c}\text { Fresh mass/ } \\
\text { Shoot } \\
(\mathrm{g})\end{array}$ & $\begin{array}{c}\text { Number of } \\
\text { nodes/ shoot }\end{array}$ \\
\hline 0 & control & $2.33 \pm 1.52$ & $0.22 \pm 0.07$ & $4.60 \pm 0.79$ & $0.09 \pm 0.02$ & $5.00 \pm 1.00$ \\
0.28 & BAP & $4.33 \pm 0.57^{\mathrm{a}}$ & $0.28 \pm 0.08^{\mathrm{a}}$ & $2.10 \pm 0.26^{\mathrm{c}}$ & $0.07 \pm 0.02^{\mathrm{a}}$ & $4.30 \pm 1.52^{\mathrm{a}}$ \\
& Kin & $2.33 \pm 0.57^{\mathrm{a}}$ & $0.74 \pm 0.16^{\mathrm{c}}$ & $2.77 \pm 0.25^{\mathrm{c}}$ & $0.07 \pm 0.02^{\mathrm{a}}$ & $3.33 \pm 0.57^{\mathrm{b}}$ \\
0.56 & BAP & $9.67 \pm 2.08^{\mathrm{c}}$ & $0.76 \pm 0.18^{\mathrm{c}}$ & $2.87 \pm 0.83^{\mathrm{c}}$ & $0.06 \pm 0.04^{\mathrm{a}}$ & $3.33 \pm 0.57^{\mathrm{b}}$ \\
& Kin & $4.33 \pm 0.57^{\mathrm{a}}$ & $0.84 \pm 0.05^{\mathrm{c}}$ & $3.10 \pm 0.36^{\mathrm{c}}$ & $0.06 \pm 0.01^{\mathrm{a}}$ & $3.00 \pm 1.00^{\mathrm{c}}$ \\
& BAP & $6.00 \pm 1.00^{\mathrm{b}}$ & $0.65 \pm 0.08^{\mathrm{c}}$ & $3.37 \pm 0.55^{\mathrm{b}}$ & $0.08 \pm 0.01^{\mathrm{a}}$ & $3.33 \pm 0.57^{\mathrm{b}}$ \\
1.12 & Kin & $2.67 \pm 0.57^{\mathrm{a}}$ & $0.68 \pm 0.03^{\mathrm{c}}$ & $3.10 \pm 0.36^{\mathrm{c}}$ & $0.05 \pm 0.00^{\mathrm{a}}$ & $3.33 \pm 0.57^{\mathrm{b}}$ \\
& BAP & $5.33 \pm 1.52^{\mathrm{b}}$ & $0.70 \pm 0.11^{\mathrm{c}}$ & $0.97 \pm 0.20^{\mathrm{c}}$ & $0.05 \pm 0.01^{\mathrm{a}}$ & $2.33 \pm 0.57^{\mathrm{c}}$ \\
2.24 & Kin & $4.00 \pm 1.00^{\mathrm{a}}$ & $0.85 \pm 0.18^{\mathrm{c}}$ & $1.83 \pm 0.15^{\mathrm{c}}$ & $0.04 \pm 0.00^{\mathrm{a}}$ & $3.33 \pm 0.57^{\mathrm{b}}$ \\
& $4.67^{\mathrm{C} D}$ & 0.18 & 0.98 & 0.06 & 0.92 \\
LSD at $5 \%$ & 6.80 & 0.39 & 2.30 & 0.11 & 1.94 \\
\hline
\end{tabular}

Values are means of three replicates \pm standard deviation (SD). Different letters indicate statistically significant differences between groups (mean $\pm \mathrm{SD}$, a not significant, $\mathrm{b}$ significant at $p<0.05$, $\mathrm{c}$ highly significant at $p<0.01$ ).

To study the effect of medium strength and type on shoot multiplication, in vitro-obtained nodal segments were cultured for three weeks on different strengths of MS medium [0.5 (half strength), 1.0 (full strength), 2.0 (double strength)] as well as full strengths of SH, WPM and B5, each of them was supplemented with $0.56 \mathrm{mg} \mathrm{l}^{-}$ ${ }^{1}$ BAP. The highest shoot number (8.33) and the best growth were obtained when explants were multiplied on full strength MS medium. The data indicated that the number of formed shoots was decreased when the concentrations of MS components were more or less than MS full strength. WPM or B5 stimulated poor shoot multiplication and growth. On the other side, explants cultured on SH medium showed better shoot regeneration more than WPM or B5 but still lower than that of full strength MS. The formation of callus at the base of explant was essential prerequisite for the formation of valuable number of regenerated shoots. In 
this concern, MS in full strength and SH media showed the same effect. The mass of callus on SH medium was larger than that of MS and it associated with shorten the length of formed shoots.

Expression of SOD was influenced by chemical components of the cultured media supplemented with $0.56 \mathrm{mg} \mathrm{l}^{-1}$ of BAP (Fig. 4, Table 5). Two medium (double MS medium and B5) expressed SOD-5 but it was not detected under the other conditions. In addition, SOD-3 was detected only when WPM medium was used (lane 5). The appearance of these extra bands (SOD-3 or SOD-5) was associated with the increase of staining intensity of all the detected isoforms. Generally, the staining intensity of SOD bands decreased when the culture conditions was suitable for moringa multiplication, on full strength MS and $\mathrm{SH}$ media.

Table 4: Effect of medium type and MS strengths on shoot multiplication and growth of in vitro grown shoots for three weeks, each type of medium containing $0.56 \mathrm{mg} . \mathrm{L}^{-1} \mathrm{BAP}$

\begin{tabular}{cccccc}
\hline $\begin{array}{c}\text { Medium } \\
\text { Type }\end{array}$ & $\begin{array}{c}\text { Number of } \\
\text { shoots/ explants }\end{array}$ & $\begin{array}{c}\text { Fresh mass/ } \\
\text { Cluster } \\
(\mathrm{g})\end{array}$ & $\begin{array}{c}\text { Length of shoot } \\
(\mathrm{cm} .)\end{array}$ & $\begin{array}{c}\text { Fresh mass/ Shoot } \\
(\mathrm{g})\end{array}$ & $\begin{array}{c}\text { Number of nodes/ } \\
\text { shoot }\end{array}$ \\
\hline MS (control) & $8.33 \pm 1.52$ & $1.29 \pm 0.40$ & $2.70 \pm 0.30$ & $0.05 \pm 0.01$ & $5.00 \pm 1.00$ \\
Half MS & $5.00 \pm 1.73^{\mathrm{b}}$ & $0.66 \pm 0.30^{\mathrm{b}}$ & $1.13 \pm 0.15^{\mathrm{c}}$ & $0.03 \pm 0.01^{\mathrm{a}}$ & $4.00 \pm 1.00^{\mathrm{a}}$ \\
Double full & $3.00 \pm 1.00^{\mathrm{c}}$ & $0.56 \pm 0.06^{\mathrm{b}}$ & $2.13 \pm 0.25^{\mathrm{a}}$ & $0.05 \pm 0.01^{\mathrm{a}}$ & $3.33 \pm 0.57^{\mathrm{b}}$ \\
MS & $6.67 \pm 2.08^{\mathrm{a}}$ & $1.09 \pm 0.51^{\mathrm{a}}$ & $2.07 \pm 0.36^{\mathrm{b}}$ & $0.06 \pm 0.01^{\mathrm{a}}$ & $4.33 \pm 0.57^{\mathrm{a}}$ \\
SH & $1.33 \pm 0.57^{\mathrm{c}}$ & $0.22 \pm 0.05^{\mathrm{c}}$ & $1.47 \pm 0.25^{\mathrm{b}}$ & $0.03 \pm 0.01^{\mathrm{a}}$ & $2.33 \pm 0.57^{\mathrm{c}}$ \\
WPM & $2.33 \pm 0.57^{\mathrm{c}}$ & $0.27 \pm 0.22^{\mathrm{c}}$ & $1.20 \pm 0.36^{\mathrm{c}}$ & $0.06 \pm 0.02^{\mathrm{a}}$ & $3.00 \pm 1.00^{\mathrm{b}}$ \\
B5 & 1.80 & 0.32 & 0.59 & 0.03 & 1.40 \\
LSD at 5\% & 4.33 & 0.74 & 1.33 & 0.06 & 2.20 \\
LSD at 1\% & & & & & \\
\hline
\end{tabular}

Values are means of three replicates \pm standard deviation (SD). Different letters indicate statistically significant differences between groups (mean $\pm \mathrm{SD}$, a not significant, $\mathrm{b}$ significant at $p<0.05$, $\mathrm{c}$ highly significant at $p<0.01$ ).

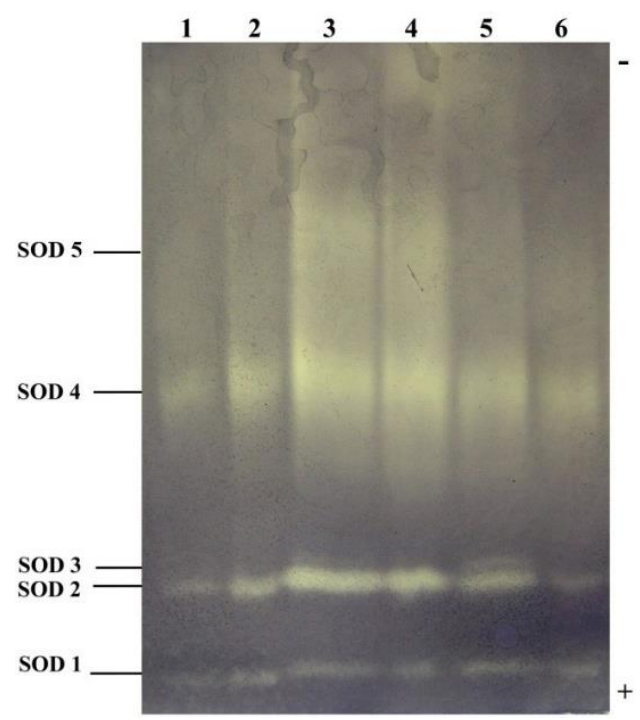

Figure 4: Native gel electrophoresis of SOD isoenzyme pattern of moringa shoots subcultured on full (lane 1), half (lane 2) and double MS medium (lane 3) as well as B5 (lane 4), WPM (lane 5) and SH media (lane 6) for three week, each of them was supplemented with $0.56 \mathrm{mg} . \mathrm{l}^{-1} \mathrm{BAP}$. 
Table 5: SOD isozyme electrophoretic patterns of moringa shoots subcultured on full (lane 1), half (lane 2) and double MS medium (lane 3) as well as B5 (lane 4), WPM (lane 5) and SH media (lane 6) for three week, each of them was supplemented with $0.56 \mathrm{mg} . \mathrm{l}^{-1} \mathrm{BAP}$

\begin{tabular}{ccccccc}
\hline & Full MS & Half MS & double MS & B5 & WPM & SH \\
\hline SOD 5 & & & ++ & ++ & & + \\
SOD 4 & + & + & ++ & ++ & + & + \\
SOD 3 & & + & & & ++ & + \\
SOD 2 & + & ++ & ++ & ++ & + & + \\
SOD 1 & + & + & + & + & & + \\
& $+=$ low intensity & ++ & intermediate & +++ high intensity & & \\
\hline
\end{tabular}

Eleven different peroxidase isoenzyme forms were detected (Fig. 5, Table 6). Ten of eleven isoenzyme forms were detected when shoots were subcultured on different media. Two isoenzyme forms (POX-2 and POX-4) disappeared when shoots were cultured on WPM. Shoots subcultured on full strength MS (lane 1) showed the lowest staining intensity of most isoenzyme forms. It's worthy to mention that staining intensity increased when the concentrations of MS components were more than or less than full strength MS.

Catalase pattern (data not shown) showed that all of the subcultured shoots on different media expressed the same isoenzyme forms but two of them disappeared in shoots subcultured on double MS. High staining intensity was detected when shoots were cultured on full strength MS or $\mathrm{SH}$.

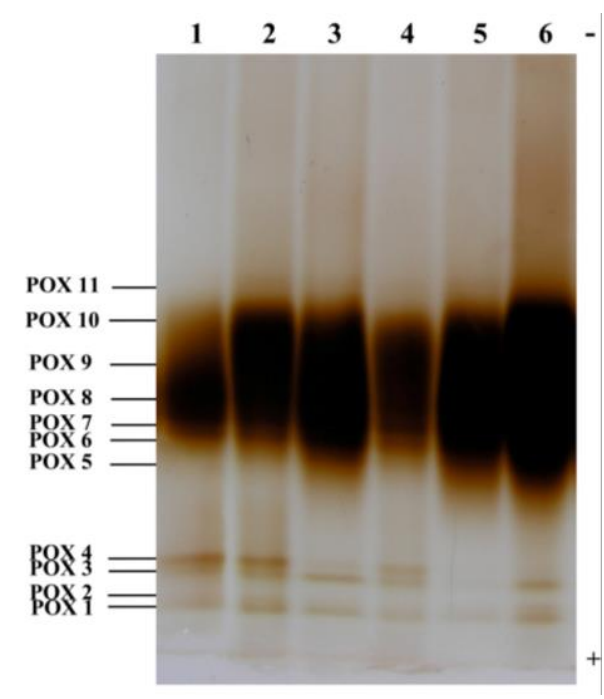

Figure 5: Native gel electrophoresis of POX isoenzyme pattern of moringa shoots subcultured on full (lane 1), half (lane 2) and double MS medium (lane 3) as well as B5 (lane 4), WPM (lane 5) and SH media (lane 6) for three week, each of them was supplemented with $0.56 \mathrm{mg} . \mathrm{l}^{-1} \mathrm{BAP}$ 
Table 6: POX isozyme electrophoretic patterns of moringa shoots subcultured on full (lane 1), half (lane 2) and double MS medium (lane 3) as well as B5 (lane 4), WPM (lane 5) and SH media (lane 6) for three week, each of them was supplemented with $0.56 \mathrm{mg} . \mathrm{l}^{-1} \mathrm{BAP}$

\begin{tabular}{|c|c|c|c|c|c|c|}
\hline & Full MS & Half MS & double MS & B5 & WPM & SH \\
\hline POX 11 & & + & + & & + & +++ \\
\hline POX 10 & + & +++ & +++ & +++ & +++ & +++ \\
\hline POX 9 & +++ & +++ & +++ & +++ & +++ & +++ \\
\hline POX 8 & +++ & +++ & +++ & +++ & +++ & +++ \\
\hline POX 7 & +++ & +++ & +++ & +++ & +++ & +++ \\
\hline POX 6 & ++ & +++ & +++ & +++ & +++ & +++ \\
\hline POX 5 & & & + & & + & + \\
\hline POX 4 & + & + & + & + & & + \\
\hline POX 3 & + & + & + & + & + & + \\
\hline POX 2 & + & + & + & + & & + \\
\hline \multirow[t]{2}{*}{ POX 1} & + & + & + & + & + & + \\
\hline & & $+=$ low & $++=i$ & & intens & \\
\hline
\end{tabular}

Staining for GOT isoenzyme (Fig. 6, Table 7) indicated that isoenzyme form GOT-3 was expressed when shoots were cultured on full MS (lane 1), WPM (lane 5) and SH media (lane 6). Isoenzyme form GOT-6 was only detected in shoots cultured on double MS (lane 3).
Generally, strong reduction of nutrient in the medium (half strength MS) resulted in disappearance of two bands (GOT-2 and GOT-3) and the lowest staining intensity.

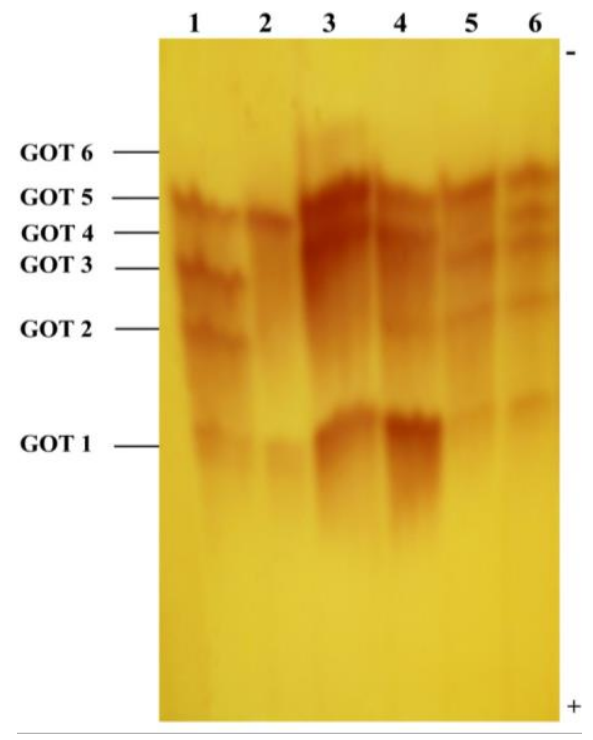

Figure 6: Native gel electrophoresis of GOT isoenzyme pattern of moringa shoots subcultured on full (lane 1), half (lane 2) and double MS medium (lane 3) as well as B5 (lane 4), WPM (lane 5) and SH media (lane 6) for three week, each of them was supplemented with $0.56 \mathrm{mg} . \mathrm{l}^{-1} \mathrm{BAP}$ 
Table 7: GOT isozyme electrophoretic patterns of moringa shoots subcultured on full (lane 1), half (lane 2) and double MS medium (lane 3) as well as B5 (lane 4), WPM (lane 5) and SH media (lane 6) for three week, each of them was supplemented with $0.56 \mathrm{mg} . \mathrm{l}^{-1} \mathrm{BAP}$

\begin{tabular}{lcccccc}
\hline & Full MS & Half MS & double MS & B5 & WPM & SH \\
\hline GOT 6 & & & + & & & \\
GOT 5 & & ++ & + & + & & \\
GOT 4 & + & + & + & + & + & + \\
GOT 3 & + & & + & + & + & + \\
GOT 2 & + & & + & ++ & + & + \\
GOT 1 & + & + & + low intensity & $++=$ intermediate & $+++=$ high intensity & \\
\hline
\end{tabular}

EST expression under the influence of different media was visualized in (Fig. 7, Table 8). A total of 18 different EST isoenzyme forms were detected especially when nodal segments were cultured on double strength MS medium. The lowest number of bands and staining intensity were detected when nodal segments were cultured on full strength MS or SH medium. Low number of EST bands with low staining intensity was detected in shoots subjected for low nutrients where they were cultured on half strength MS medium.

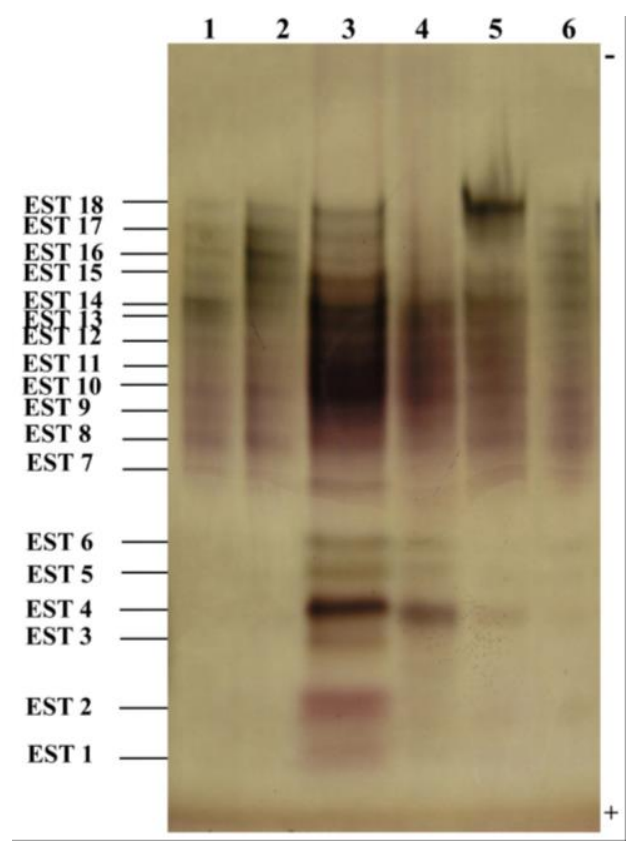

Figure 7: Native gel electrophoresis of EST isoenzyme pattern of moringa shoots subcultured on full (lane 1), half (lane 2) and double MS medium (lane 3) as well as B5 (lane 4), WPM (lane 5) and SH media (lane 6) for three week, each of them was supplemented with $0.56 \mathrm{mg} . \mathrm{l}^{-1} \mathrm{BAP}$ 
Table 8: EST isozyme electrophoretic patterns of moringa shoots subcultured on full (lane 1), half (lane 2) and double MS medium (lane 3) as well as B5 (lane 4), WPM (lane 5) and SH media (lane 6) for three week, each of them was supplemented with $0.56 \mathrm{mg} . \mathrm{l}^{-1} \mathrm{BAP}$

\begin{tabular}{|c|c|c|c|c|c|c|}
\hline & Full MS & Half MS & double MS & B5 & WPM & $\mathrm{SH}$ \\
\hline EST 18 & + & + & + & & +++ & + \\
\hline EST 17 & + & + & + & & + & + \\
\hline EST 16 & + & + & + & & + & + \\
\hline EST 15 & + & + & +++ & + & + & + \\
\hline EST 14 & + & + & +++ & + & + & + \\
\hline EST 13 & + & + & +++ & ++ & ++ & + \\
\hline EST 12 & + & + & +++ & ++ & ++ & + \\
\hline EST 11 & + & + & +++ & ++ & ++ & + \\
\hline EST 10 & + & + & +++ & ++ & ++ & + \\
\hline EST 9 & + & + & +++ & ++ & ++ & + \\
\hline EST 8 & + & + & +++ & + & + & + \\
\hline EST 7 & + & + & + & + & + & + \\
\hline EST 6 & & & + & + & & \\
\hline EST 5 & & & + & + & & \\
\hline EST 4 & & & +++ & +++ & + & + \\
\hline EST 3 & & & + & + & & \\
\hline EST 2 & & & +++ & + & & \\
\hline \multirow[t]{2}{*}{ EST 1} & & & + & + & & \\
\hline & & $+=$ low & $++=\mathrm{i}$ & & intensity & \\
\hline
\end{tabular}

\section{DISCUSSION}

Two types of explants obtained from soil growing seedlings, shoot and nodal cuttings, were used to establish shoot culture of moringa on MS medium supplemented $0.65 \mathrm{mg} \mathrm{l}^{-1}$ BAP. Nodal segments were better than shoot cuttings where they expressed higher values of frequency of shoot formation, number of shoots/explant, fresh mass/cluster and number of nodes/explant than those of shoot cuttings. Explants cultured on growth regulators free medium showed the formation of roots as was previously reported (Förster et al., 2013). Supplementing the medium with different concentrations of BAP resulted in callus formation and it increased with the increase of BAP concentrations. The variable response of different types of explant to the same culture conditions may be due to the difference in endogenous plant hormones they have (Kumar and Reddy, 2011).

On KIN containing medium, shoot formation and growth on nodal segments were better that those on shoot segments. Plants cultured on KIN medium were taller with higher number of nodes/shoot compared to BAP containing medium. Medium supplemented with BAP resulted in greater ability to form adventitious shoots. There was opposite relationship between shoot length and formation of callus at the base of nodal segments. In moringa, callus formation increased with the increase of BAP concentration (Förster et al., 2013). It was clear that both of the applied cytokinins were able to induce morphogenesis and growth in moringa. Cytokinins stimulate cell division and morphogenesis (Taiz and Zeiger, 1991), enhance the lateral bud growth due to break the apical dominance (George, 1993), and induction of adventitious bud formation. In moringa and other plant species, two of them have been using widely, they are KIN and BA (Pierik, 1997; Förster et al., 2013; Salem, 2016).

Source of explant was also important factor during moringa shoot multiplication may be due to the different values of endogenous phytohormones they contain (Reddy et al., 2008; Förster et al., 2013). Moringa 
explants obtained from established shoot culture were better than others obtained from soil growing seedling as they have better potential for organogenesis (Reddy et al., 2008). The results showed that BAP was superior in multiplication compared with KIN. In moringa as well as other plant species, specific BAP concentration led to multiplication and vegetative growth but other applied concentrations was strongly resulted in induction of callus formation (Ibrahim et al., 2013). Callus formation on the base of nodal segment on BAP containing media were higher than those of KIN, especially under the influence of high concentration as an aspect of vitrification. Vice versa, the superiority of kinetin over other BAP was sometimes proven (Parzymies and Dąbsk, 2012).

Moringa shoot multiplication was strongly influenced by the concentration of nutrients in culture media, where it expressed different values on different media or different strengths of MS medium. Between the different types of the used media, full strength MS medium was best one because it contains all the elements which inducted the best cells dedifferentiation leading to the highest adventitious shoot formation (Thorpe, 1978). In comparison to other media, MS is referred to as a high salt medium where it has high contents of nitrogen and potassium (Cohen, 1995). Reducing the salt concentration of MS medium due to application of its half strength resulted in reduction of shoot multiplication and shoot growth as was reported by Bhatt and Dhar (2004). This poor performance with regard to the determined parameters was also detected when WPM was used where it characterized by low mineral content. Mineral content of SH was lower than MS but higher than B5 and WPM, consequently, the efficiency of moringa micropropagation was in parallel to mineral content of the culture media.

Under the influence of in vitro culture conditions, moringa explants as well as other plant species were subjected to extreme conditions such as wounding, medium components and others (Kumar and Reddy, 2011; Wojtania and Skrzypek, 2014; Salem, 2016). These conditions resulted in ROS accumulation leading to different physiological disorders including vitrification (Rojas-Martínez et al., 2010). Also these conditions, induce acclimation responses which allows the plants to survive under unfavorable conditions (Kevers et al., 2004). The suitable medium for micropropagation of certain plant, such as full strength MS in case of moringa, exerted low stress and low need to rise the activities of antioxidant enzymes such as SOD, CAT and POX. Increase in the activity of an enzyme is expressed as increase in the number of bands or the staining intensity of all or some isoenzyme forms. Generally, the staining intensity of SOD bands decreased when the culture conditions was suitable for moringa multiplication, on full strength $\mathrm{MS}$ and $\mathrm{SH}$ media. On the other side, over increase of chemical components of the cultured medium (as in case of double MS medium) or on medium with low mineral component (as in case of B5 or WPM) moringa shoots expressed the highest number and staining intensity of SOD bands. Both POX and CAT create cooperation with SOD to overcome the toxic effect of $\mathrm{H}_{2} \mathrm{O}_{2}$. In this work, the lowest staining intensity of most isoenzyme forms of POX was detected under favorite condition of moringa in vitro culture. On the other side, high staining intensity of CAT was detected when shoots were cultured on full strength MS or SH. These enzymes established efficient system to regulate the elevated oxidative stress due to in vitro culture condition which stimulate in vitro shoot multiplication.

Since the high salt content of the medium may inhibit root formation and growth irrespective the type and concentration of auxin, half strength MS medium containing $0.5 \mathrm{mg} \mathrm{l}^{-1}$ IAA was usually used to induce root formation in moringa as was reported by (Sauer et al., 1985). The plants were successfully transferred to open condition after three weeks acclimatization.

\section{CONCLUSION}

In vitro obtained nodal segments cultured on full strength MS medium containing $0.56 \mathrm{mg} \mathrm{l}^{-1}$ of BAP is recommended for efficient moringa micropropagation without severe verification or retardation of root formation and successful acclimatization.

\section{REFERENCES}

Anwar, F., \& Bhanger, M. I. (2003). Analytical characterization of Moringa oleifera seed oil grown in temperate regions of Pakistan. Journal of
Agricultural and food Chemistry, 51(22), 65586563. https://doi.org/10.1021/jf0209894

Beauchamp, C., \& Fridovich, I. (1971). Superoxide dismutase: improved assays and an assay applicable 
to acrylamide gels. Analytical biochemistry, 44(1), 276-287. 2697(71)90370-8

Bhatia, S., Othman, Z., \& Ahmad, A. L. (2007). Coagulation-flocculation process for POME treatment using Moringa oleifera seeds extract: optimization studies. Chemical Engineering Journal, 133(1), 205-212. https://doi.org/10.1016/j.cej.2007.01.034

Bhatt, I. D., \& Dhar, U. (2004). Factors controlling micropropagation of Myrica esculenta buch.-Ham. ex D. Don: a high value wild edible of Kumaun Himalaya. African Journal of Biotechnology, 3(10), 534-540. https://doi.org/10.5897/AJB2004.0002097

Brewer, G. J., \& Sing, C. F. (1970). Introduction to isozyme techniques.

Caceres, A., Saravia, A., Rizzo, S., Zabala, L., De Leon, E., \& Nave, F. (1992). Pharmacologie properties of Moringa oleifera. 2: Screening for antispasmodic, antiinflammatory and diuretic activity. Journal of Ethnopharmacology, 36(3), 233-237. https://doi.org/10.1016/0378-8741(92)90049-W

Chen, J., \& Ziv, M. (2001). The effect of ancymidol on hyperhydricity, regeneration, starch and antioxidant enzymatic activities in liquidcultured Narcissus. Plant Cell Reports, $20 . \quad 22-27$. https://doi.org/10.1007/s002990000283

Church World Service. 2000. Moringa oleifera-the miracle tree. Church World Service. 3.

Classic Murashige, T., \& Skoog, F. (1962). A revised medium for rapid growth and bioassays with tobacco tissue cultures. Physiologia Plantarum, 15, 473-97. https://doi.org/10.1111/j.13993054.1962.tb08052.x

Cohen, D. (1994). The culture medium. Environmental Effects and their Control in Plant Tissue Culture 393, 15-24.

Devi, P., Satyanarayana, B., Arundhati, A., Rao, T. (2013). Activity of antioxidant enzymes and secondary metabolites during in vitro regeneration of Sterculia urens. Biologia Plantarum, 57, 778782. https://doi.org/10.1007/s10535-013-0337-x

Dillard, C. J., \& German, J. B. (2000). Phytochemicals: nutraceuticals and human health. Journal of the Science of Food and Agriculture, 80(12), 1744$1756 . \quad$ https://doi.org/10.1002/10970010(20000915)80:12<1744::AIDJSFA725>3.0.CO;2-W

Fahey, J. W. (2005). Moringa oleifera: A Review of the Medical Evidence for Its Nutritional, Therapeutic, and Prophylactic Properties. Part 1. Trees for life Journal, 1(5).

Förster, N., Mewis, I., \& Ulrichs, C. (2013). Moringa Oleifera-Establishment and Multiplication of Different Ecotypes In Vitro. Gesunde Pflanzen, 65(1), 21-31. https://doi.org/10.1007/s10343-013-0291-8

Gamborg, O. L., Miller, R., \& Ojima, K. (1968). Nutrient requirements of suspension cultures of soybean root cells. Experimental cell research, 50(1), 151-158. https://doi.org/10.1016/0014-4827(68)90403-5

George, E. F. (1993). Plant propagation by tissue culture. Part 1: the technology (No. Ed. 2). Exegetics limited.

Gnamien, Y. G., Bi, Z., Arsène, I., Kouadio, Y. J., Brostaux, Y., \& Baudoin, J. P. (2013). Medium effects on micropropagation and genetic stability of Citrullus lanatus oleaginous type. Agricultural Sciences, 4(07), $32-44$. https://doi.org/10.4236/as.2013.47A005

Guevara, A. P., Vargas, C., Sakurai, H., Fujiwara, Y., Hashimoto, K., Maoka, T., ... \& Nishino, H. (1999). An antitumor promoter from Moringa oleifera Lam. Mutation Research/Genetic Toxicology and Environmental Mutagenesis,440(2), 181-188. https://doi.org/10.1016/S1383-5718(99)00025-X

Hassanein, A. M., Ahmed, A. M., \& Soltan, D. M. (2008). Study of somaclonal variation and gene expression as influenced by long term culture in sorghum. Current Opinion in Biotechnology, 4, 1320 .

Hassanein, A. M., El-Sherbeeny, G. R., Kalid, A. S. G., \& Gaboor, G. M. (2015). Seed propagation increases genetic variation and micropropagation to multiply selected shrub with desirable characters. Journal of International Scientific Publications, 3, 325-339.

Hassanein, A.M., Salem, J.M., Faheed, F.A., \& Elnagish A. (2018). Effect of anti-ethylene compounds on isoenzyme patterns and genome stability during long term culture of Moringa oleifera. Plant Cell ,Tissue and Organ Cultutre, 132(1), 201-212. https://doi.org/10.1007/s11240$017-1326-0$

Ibrahim, M. A., Al-Taha, H., \& Seheem, A. A. (2013). Effect of cytokinin type and concentration, and source of explant on shoot multiplication of pineapple plant (Ananas comosus' Queen') in vitro/Ucinek vrst in koncentracij citokininov ter vira stebelnih izseckov na in vitro razmnozevanje ananasa (Ananas comosus' Queen'). Acta 
agriculturae Slovenica, 101(1), https://doi.org/10.2478/acas-2013-0002

15.

Islam, S., Jahan, M. A. A., \& Khatun, R. (2005). In vitro regeneration and multiplication of year-round fruit bearing Moringa oleifera L. Journal of Biological Sciences $\quad, 5, \quad 145-148$. https://doi.org/10.3923/jbs.2005.145.148

Kevers, C., Franck, T., Strasser, R. J., Dommes, J., \& Gaspar, T. (2004). Hyperhydricity of micropropagated shoots: a typically stress-induced change of physiological state. Plant Cell, Tissue and Organ Culture, 77(2), 181-191. https://doi.org/10.1023/B:TICU.0000016825.18930 .e4

Kumar, N., \& Reddy, M. P. (2011). In vitro plant propagation: a review. Journal of Forest and Environmental Science, 27(2), 61-72.

Lloyd, G., \& McCown, B. (1980). Commerciallyfeasible micropropagation of mountain laurel, Kalmia latifolia, by use of shoot-tip culture. Combined Proceedings. International Plant Propagators' Society, 30, 421-427.

McCown, B. H., \& Sellmer, J. C. (1987). General media and vessels suitable for woody plant culture. In: Cell and tissue culture in forestry (pp. 4-16). Springer Netherlands. https://doi.org/10.1007/97894-017-0994-1_2

Mirzai, F., Uliaie, E.D., \& Hagh, A.B. (2015). Stimulation Effect of $\mathrm{AgNO} 3$ and $\mathrm{CoCl} 2$ as Ethylene Inhibitors on in-Vitro Organogenesis of Sunflower (Helianthus annuus L.). Journal of Agricultural Science, 25(2), 113-118.

Morton, J. F. (1991). The horseradish tree, Moringa pterygosperma (Moringaceae) - a boon to arid lands?. Economic botany,45(3), 318-333. https://doi.org/10.1007/BF02887070

Murakami, A., Kitazono, Y., Jiwajinda, S., Koshimizu, K., \& Ohigashi, H. (1998). Niaziminin, a thiocarbamate from the leaves of Moringa oleifera, holds a strict structural requirement for inhibition of tumor-promoter-induced Epstein-Barr virus activation. Planta Medica, 64(04), 319-323. https://doi.org/10.1055/s-2006-957442

Ndabigengesere, A., \& Narasiah, K. S. (1998). Quality of water treated by coagulation using Moringa oleifera seeds. Water research,32(3), 781-791. https://doi.org/10.1016/S0043-1354(97)00295-9

Parzymies, M., \& Dąbski, M. (2012). The effect of cytokinin types and their concentration on in vitro multiplication of Clematis viticella (L.) and Clematis integrifolia 'Petit Faucon'. Acta
Scientiarum . Polonorum, Hortorum Cultus, 11(1), 81-91.

Pawar, U. R., \& Panneerselvam, R. (2012). Changes of protein content, activity and active isoforms of antioxidative enzymes in Excoecaria agallocha under salt stress. International Journal of Research in Plant Science, 2(4), 62-66.

Pierik, R. L. M. (1997). In vitro culture of higher plants. Springer Science \& Business Media.

Reddy, M. P., Kumar, N., Vijay Anand, K. G., Singh, A. H., \& Singh, S. (2008). Method for micropropagation of Jatropha curcas plants from leaf explants. Patent filed US and PCT, Application, (2537).

Riyathong, T., Dheeranupattana, S., Palee, J., \& Shank, L. (2010). Shoot Multiplication and Plant Regeneration from In vitro cultures of drumstick tree (Moringa oleifera Lam.). In: Proceedings of the 8th International Symposium on Biocontrol and Biotechnology. King Mongkut's Institute of Technology Ladkrabang and Khon Kaen University, Nongkhai Campus, Thailand, 99-104

Rojas-Martínez, L., Visser, R. G., \& de Klerk, G. J. (2010). The hyperhydricity syndrome: waterlogging of plant tissues as a major cause. Propagation of Ornamental Plants, 10(4), 169-175.

Rout, J., Ram, S., Das, R., Chakraboty, A., Sudarshan, M., \& Sahoo, S. (2013). Copper-stress induced alterations in protein profile and antioxidant enzymes activities in the in vitro grown Withania somnifera L. Physiology and Molecular Biology of Plants, 19(3),353-361. https://doi.org/10.1007/s12298-013-0167-5

Salem, J. M. (2016). In vitro propagation of Moringa oleifera L. under salinity and ventilation conditions. Genetics and Plant Physiology, 6(1-2), 54-64.

Sánchez, N. R., Ledin, S., \& Ledin, I. (2006). Biomass production and chemical composition of Moringa oleifera under different management regimes in Nicaragua. Agroforestry Systems, 66(3), 231-242. https://doi.org/10.1007/s10457-005-8847-y

Sauer, A., Walther, F., \& Preil, W. (1985). Different Suitability for in vitro Propagation of Rose Cultivars/Sortentypische Eignung von Rosen für in vitro Vermehrung. Gartenbauwissenschaft, 133138.

Schenk, R. U., \& Hildebrandt, A. C. (1972). Medium and techniques for induction and growth of monocotyledonous and dicotyledonous plant cell cultures. Canadian Journal of Botany, 50(1), 199204. https://doi.org/10.1139/b72-026 
Sharma, G. K., \& Raina, V. (1982). Propagation techniques of Moringa oleifera Lam. In: Improvement of forest biomass: symposium proceedings/edited by PK Khosla. Solan, India: Indian Society of Tree Scientists, c1982..

Siddhuraju, P., \& Becker, K. (2003). Antioxidant properties of various solvent extracts of total phenolic constituents from three different agroclimatic origins of drumstick tree (Moringa oleifera Lam.) leaves. Journal of agricultural and food chemistry, 51(8), 2144-2155. https://doi.org/10.1021/jf020444+

Siegel, B. Z., \& Galston, A. W. (1967). The isoperoxidases of Pisum sativum. Plant Physiology, 42(2), 221-226. https://doi.org/10.1104/pp.42.2.221

Snedecor, G.W., \& Ochran, W.G. (1980). Statistical methods. Oxford and J. B. H. Publishing Com. 7th. In: I. A. Ames (ed.). - Iowa State University, 166190.

Stephenson, K. K., \& Fahey, J. W. (2004). Development of tissue culture methods for the rescue and propagation of endangered Moringa spp. germplasm. Economic botany, 58(sp1), 116-124. https://doi.org/10.1663/00130001(2004)58[S116:DOTCMF]2.0.CO;2

Suarez, M., Entenza, J. M., Doerries, C., Meyer, E., Bourquin, L., Sutherland, J., ... \& Mermod, N. (2003). Expression of a plant-derived peptide harboring water-cleaning and antimicrobial activities. Biotechnology
Bioengineering, 81(1), https://doi.org/10.1002/bit.10550

Taiz, L., \& Zeiger, E. (1991). Ethylene and abscisic acid. Plant Physiology. The Benjamin/Cummings Publishing Company, Redwood City, CA, 473-489.

Thorpe, T. A. (1982). Physiological and biochemical aspects of organogenesis in vitro. In Plant tissue culture 1982: proceedings, 5th International Congress of Plant Tissue and Cell Culture held at Tokyo and Lake Yamanake, Japan, July 11-16, 1982/edited by Akio Fujiwara. Tokyo: Japanese Association for Plant Tissue Culture,[1982?]..

Ueda, Y., Uehara, N., Sasaki, H., Kobayashi, K., \&Yamakawa, T. (2013). Impacts of acute ozone stress on superoxide dismutase (SOD) expression and reactive oxygen species (ROS) formation in rice leaves. Plant Physiology and Biochemistry, 70C,396-402.

https://doi.org/10.1016/j.plaphy.2013.06.009

Wojtania, A., \& Skrzypek, E. (2014). Effects of cytokinins on antioxidant enzymes in in vitro grown shoots of Pelargonium hortorum LH Bayley. Acta agrobotanica, 67(4). https://doi.org/10.5586/aa.2014.042

Zhang, J., Lin, M., Chen, H., \& Chen, X. (2017). Agrobacterium tumefaciens-mediated transformation of drumstick (Moringa oleifera Lam.). Biotechnology and Biotechnological Equipment, $\quad 31(6), \quad 1126-1131$. https://doi.org/10.1080/13102818.2017.1368415 